\title{
SERUM SELENIUM LEVELS IN EUTHYROID NODULAR THYROID DISEASES
}

\author{
Davut Sakız ${ }^{1}$ Ahmet Kaya², Mustafa Kulaksızoğlu² \\ ${ }^{1}$ Necmettin Erbakan University, Meram School of Medicine, Department of Internal Medicine \\ ${ }^{2}$ Necmettin Erbakan University, Meram School of Medicine, Department of Endocrinology and Metabolism
}

Thyroid tissue is very sufficient to nodulation. Thyroid nodules are masses mostly improving with hiperplasia and/or hypertropy of thyroid cells, that can include cystic/solid component, and can distinguish with sonography and palpation from thyroid parenchyma. Main clinical importance of thyroid nodules is because that cancer's prevalance is between $\% 5-15$. It is not clear which mechanism is responsible for the growth of only some follicular cells resulting in nodule formation. Several studies has determined the association between thyroid gland diseases and serum selenium levels. Also at varied studies relation between selenium and some organ cancer is shown. Selenium also can be a risk factor in the development of thyroid nodüles. The aim of this study was to investigate the relationship between selenium levels in patients with euthyroid nodular thyroid diseases.

Methods:

Euthyroid 70 patients with identified single thyroid nodule, euthyroid 70 patients with detected multiple thyroid nodules and control group of euthyroid 60 people without nodule formation included in the study. Sera obtained from participants stored at $-80^{\circ} \mathrm{C}$ until all samples have collected. Then from this serums selenium levels were studied collectively with spectrometric method.

Selenium levels of patients with multiple thyroid nodules, solitary nodules and patients without nodules respectively $57.3 \pm 1.76 ; 58.7 \pm 1.80$ and $57.6 \pm 1.71 \mu \mathrm{g} / \mathrm{L}$ was detected. The mean serum selenium level of all patients included in the study was $57.92 \pm 14.43 \mu \mathrm{g} / \mathrm{L}$. Serum selenium levels were minimal higher in men, although statistically significant difference was not observed. Also nodule sizes were not differ with serum selenium levels. In our study, significant relationship between serum selenium levels and nodular thyroid disease has not been determined.
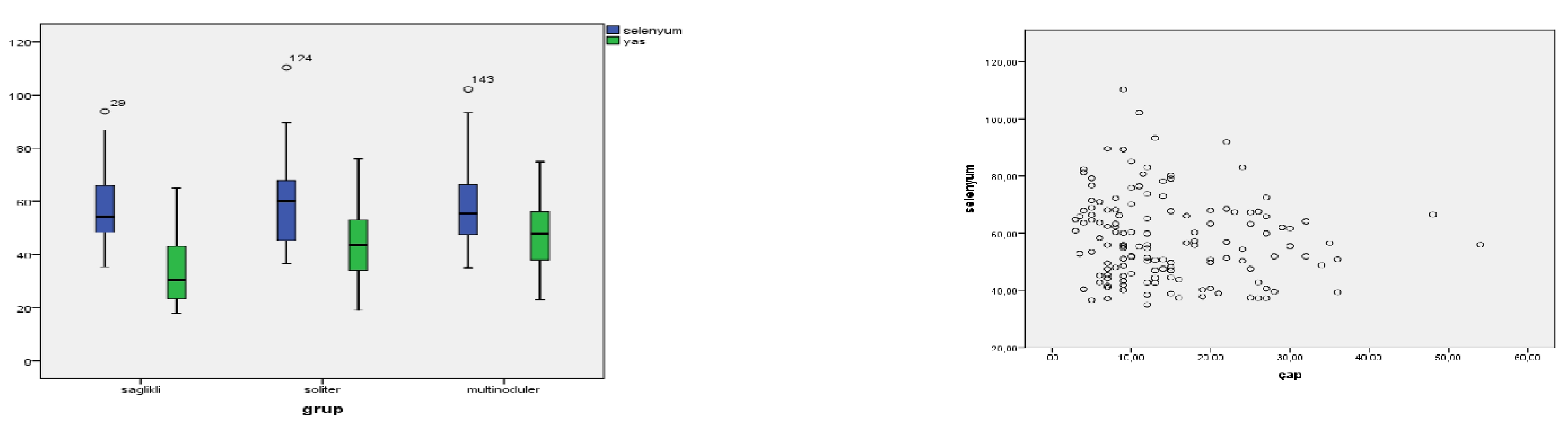

Our study with volunteers from iodine sufficient area Konya, serum selenium levels were lower compared to other studies in Turkey. This condition is associated with the low selenium contents of the soil. Nodular thyroid disease shows multifactorial features. Besides iodine deficiency additional factors such as selenium deficiency can be effective in the increase of nodule formation. Further investigations about the level of selenium deficiency and to evaluate it's effects on public health and the aetiology of nodular thyroid disease studies are necessary in Turkey.

3.Karadaș F. Scientific data on selenium status in Turkey. Agricultural Sciences. 2014;5(2):87-93.

4.Kishosha PA, Galukande M, Gakwaya AM. Selenium Deficiency a Factor in Endemic Goiter

Persistencein Sub-Saharan Africa. World J Surg 2011;35:1540-1545.

5.Köhrle J, Gartner R. Selenium and thyroid. Best Pract Res Clin Endocrinol Metab 2009;23:815-27

6.Kvicala J, Zamrazil V. Effect of iodine and selenium upon thyroid function. Cent Eur J public Health. 2003;11:107-13.

7.Novotny L, Rauko P, Kombian SB, Edafiogho IO. Selenium as a chemoprotective anti-cancer agent: Reality or wishful thinking? Neoplasma 2010;57: 383-391.

8.Triggiani V, Tafaro E, Giagulli VA, Sabba C, Resta F, Licchelli B, Guastamacchia E. Role of Iodine, Selenium and Other Micronutrients in Thyroid Function and Disorders.Endocr Mrtab Immune Disord Drug Targets. 2009;9:277-94. 